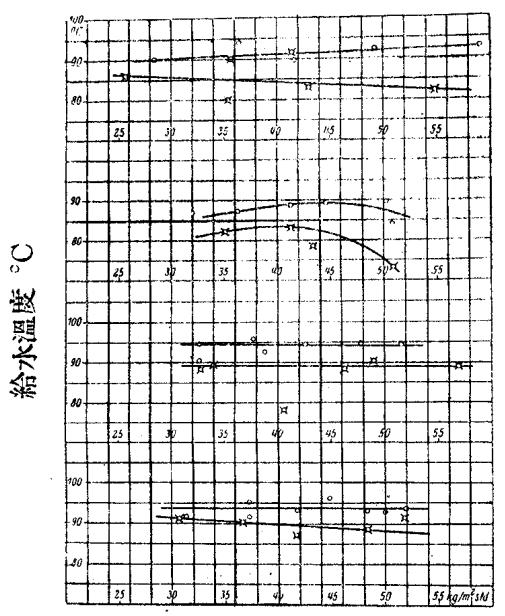

蒸媵力 $\mathrm{kg} / \mathrm{m}^{2}-\mathrm{h}$

第 5

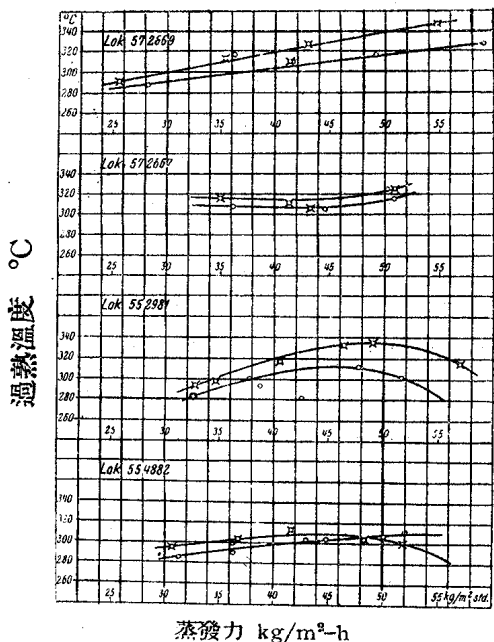

第 6
るに先づ火格 子、灰箱、煙室 內等の不燃燒残 物の熱損失は相 當大きく、之は 負街が增すと洪 に大となり、4 〜8\%である。 排侌の損失は 14〜18\% に沾 する。殘りの 2 〜4\%は輻射、 傳導等に依る缹 損失である。

次に湯垢の䈑 の費用の損失を 計算して見るに 前記の如く、洗 罐淔前の熱效裂 の低下が・ $2 \cdot 8 \%$ であり、洗敘直 後は $0 \%$ である から本均 $1.4 \%$ と見る可きであ る。今權效率を 平均 $80 \%$ と取 る時は石炭消費 量の比は は 80 : (80-1*4) 或は 1: 1.0178 でま る。 (田中)

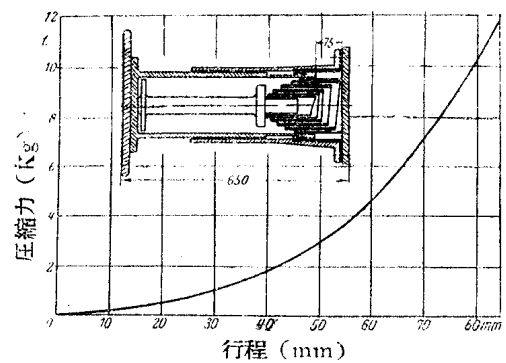

第 1 圖蓦参バネ式緩街器

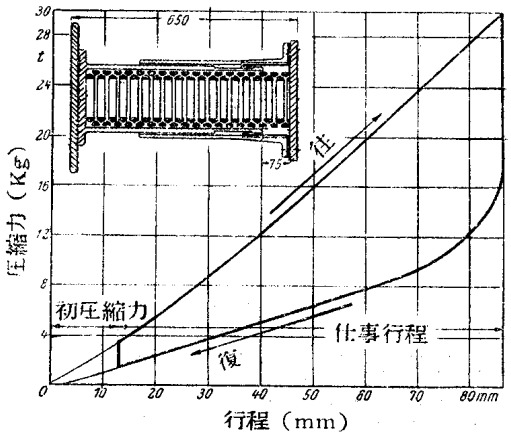

第 2 圆藦擦式緩衝器
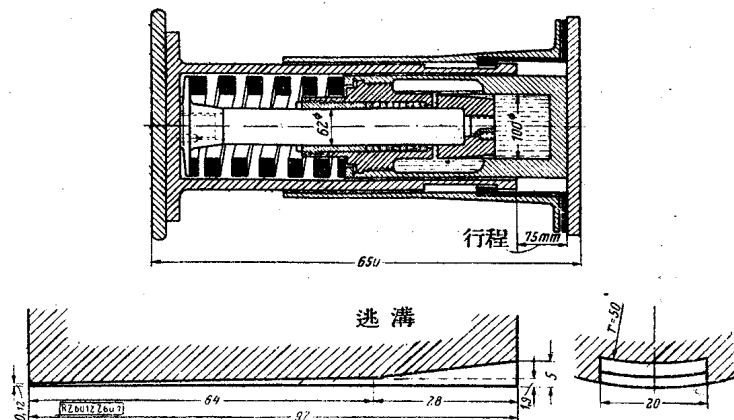

第 3 圖液體式緩衝器

【32】車輛用緩衝裝置の特性比較試驗 〔P、

Langer, VDI, 1931-8-8, 頁 1013-1018] 貨車 に數種の緩衝裝置を炆付け靜止の 1 輛に他の 1 輛を衝突せしめ車の受付ける減速度 (衝摹) を澌 定した試驗結果が示されてるる。使用した緩衝器 は裳卷バネ式 12 的緩衝器 (第 1 圖參照)、摩擦 式 30 䎲䌊㣫器 (第 2 圖參照)、及液體式 60 䣩 䌊㣫器 (第 3 圖參照) の 3 種類で之を自電 $13 \mathrm{t}$ の貨車 2 輛に取 付け荷重及㣫擊速度の變化に對 さる減速度の值を求めた。“試驗の結果衝擊速度 $v_{1}$ を橫軸に最大減速度 $b_{\max }$ を縱軸に取れば空 車の場合 $\left(Q_{m} \cong 13 \mathrm{t}\right)$ 及盈車の場合 $(Q \cong 31 \mathrm{t})$ に對し夫ミ第 4 圖及第 5 圖が得られ又貨車重量 を横軸に減速度を縱軸に取れば偅擊速度 $5 \mathrm{~km} / \mathrm{h}$, $10 \mathrm{~km} / \mathrm{h}$, 及 $15 \mathrm{~km} / \mathrm{h}$ に對し夫々第 6 圖、第 7 圖及第 8 圖が得られる。尚之等の緩衝器の行程は各 $75 \mathrm{~mm}$ と し、固定緩衝器及一定王力緩衝器 (全行程中緩㣫力がー 昭和 7 年 2 月]

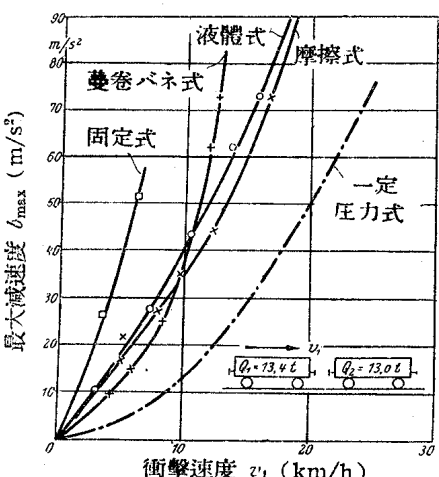

第 4

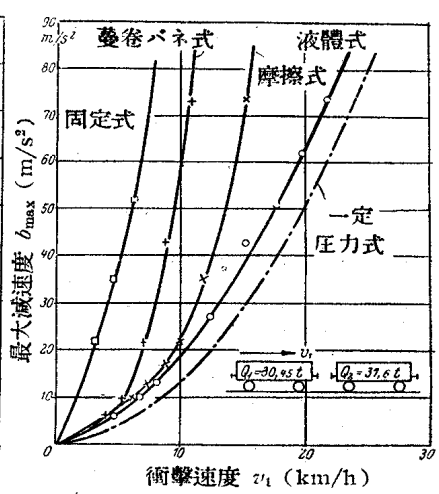

第 5

啕
定なる如き緩衝器）の特性を兩㥛端の限度として付加へ た。

上述の結果より明なる如く $Q=13 \cdot 2 \mathrm{t}$ の時は㣫撃速 


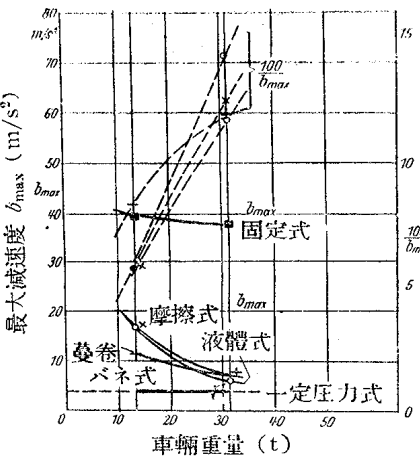

第 6 圖

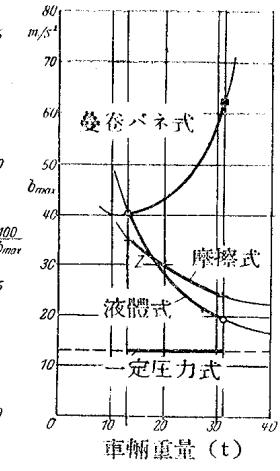

第 7

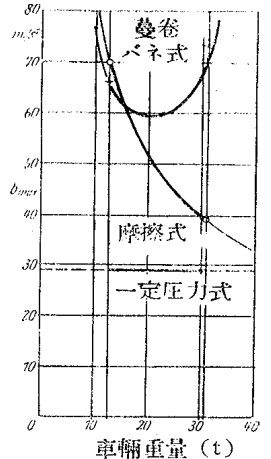

第 8
度 $9 \mathrm{~km} / \mathrm{h}$ 以下に於ては夏尞バネ式最も 衝慗少く更に速度が高くなれば摩擦式が 最小となり (第 4 圖參照) 液體式は磨擦 式より僅かに高く $v_{1}$ の墰加と共に其の 着は減少する。次に第 7 圖 $\left(v_{1}=10\right.$ $\mathrm{km} / \mathrm{h})$ に見る如く磨擦式と液體式は $Z$ 點 $Q=18 \mathrm{t}$ に於て相合し蕧卷バネ式は 之等より遥に高くなる第 8 圖 $\left(v_{1}=15\right.$ $\mathrm{km} / \mathrm{h})$ に於ては液體式は衝謷最少とな る。又第 5 圖に見る如く盈車の場合には 液體式は $\sigma_{1}=6 \mathrm{~km} / \mathrm{h}$ 以上は他のもの よりも遥に衝㢣少く之等の點より見て液 體式は重量の大なる車輛に最も適 當であ る事が知られる。

(筐柇)

\section{4. 水力及水力機}

【33】導水設備に於ける噪言の減殺に就て [H. Reiher, K. Sippell, J. Lindner, VDI, 1931-5-30 真 681-686]噪音の發生と傳播に就て述べ其淢殺装置を考 察して噪吾の發生は防止でき妋しても傳播を防止し得 る事を述べてるる。實驗裝置としては徑 3/4 时長さ 29 米の卧鉛鍍鐵管 2 本を本行して設け其一端を結び其處 に市の水道から給水して 1 本は通常の状態に他の 1 本 に實驗すべき諸種の裝置を施して此較試驗したので高周 波を避ける笉篦電微恿計を用ひ擴大器により之を自記周 波計に棓錄なさしめてるる。導水管の音には理諭上次の 3 種がある、1. 管內を流孔る渦動により管整及曲管部 站に面積の變化する點に於て發生するもので振動數 100 位の㬋音で水中を傳播する。2. 玨少の降下により水中 から瓦斯水蒸元が放出する䉆に出るもので振動數 600 700 の茼音で管譬を傳播する。 $3.8 \mathrm{~m} / \mathrm{sec}$ 位に望する 放出水が放出栓の壁及隅等に衝突して發生するもの。ゴ ム、コルク等を用ひて管照を中聯する場合噪番の減少度 合は殘存音量と最初の盖量との比 $\eta$ で表はされ、堅さ の此を $n$ ，厚さを $h$, 波長を $\lambda$ とすれ就 $\eta=1 /\left(n^{2} h / \lambda \cdot \pi\right.$ +1）で表はされ振動數 600 とすれば $1 \mathrm{~mm}$ 厚のゴム を用ひ $\eta=0.02$ となるから殆ど總ての音が吸收される 事になる。數段に減压する事によつて水中を傅播する噪

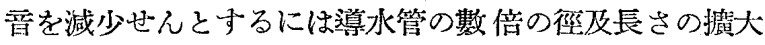
部を作り其中に玉杪利等の球形のものを塤充し通過し得 る自由面積を全面積の $1 / 2$ - 1/4 にする事が行はれ、其 場合自由面積と全面積との比が 0.3 と寸れば $3 / 4$ 时の 導水管に對し長さ 5 糎の拱大部に對し振動數 100 のも
のは $\eta=0.37,600$ のものは $\eta=0.51$, 長さ 10 糎の

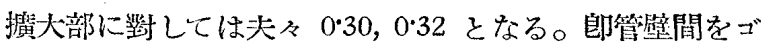
ム、コルク等を以て中断すれば蓄音が避けられ、擴大部 を用ひれば喉昔方減少する事か知られる。次に放出柽の 種類による噪音の高低が調べてある、上下に弁を有する 化粧棱、普通活栓 (ストップ弁)、滑り活柽 (スルース 弁）に就て普通活栓と比較して見るに、化粧栓は水量 10 〜20l/mn では 1 ホーン小さいが $27 \mathrm{l} / \mathrm{mn}$ で急激に 6 ホーン高くなる、之に措大部減音裝置をつければ一體 に6ホーン小さくなり $23 \mathrm{l} / \mathrm{mn}$ の限界點ですら普通活 栓より 1 ホーン低くなる、滑り活栓では擴大部減音裝 置が大して效果なく 6〜8 ホーン低くなつてるる。普通 活栓に減音裝置をつければ水量が $45 \mathrm{l} / \mathrm{mn}$ 迄 6 ホーン 減じ $70 \mathrm{l} / \mathrm{mn}$ で 4 ホーン減じてるる。又活水烃は減音

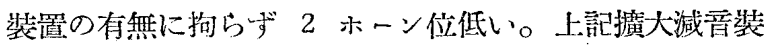

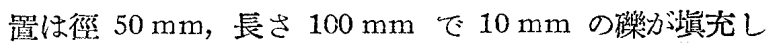

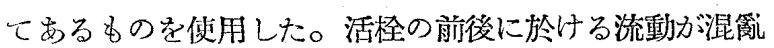
せ㨾流動力向に平行な多數の隔献を作つて見たが全然 效果がなかつた。曲管部を連續して多數作つて見たが是 も殆ど效果なく、8 ケの俩立つた連續曲りにより多少弱 くなつたかと思はれる位で、8ラの丸い連續朋りでは幾 分振動が細かくなつたかに感じられる琣で要つた。又䢖

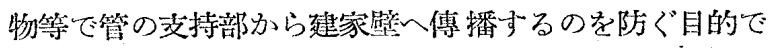
ホフランネル等で支持金具の支持面を張つて見たとこ ろ、緒しく振播を減ずる事ができた。原書には前記其他 整々の場合の周波寫傎が 16 出てをり、之を含めて圆が 27 載せてある。

(菰田)

\section{5. 医縮機、冷却機、送風機}

【34】分篗用通風機の撰定 [P. H. N. Ulander. Mech. Wld., 1931-8-7, 14, 21, 頁 121-3, 149-51, 178-
80] 穴權空補助設備の動力消費といら題下に燃料協會で 發表されたのであるが、給炭裝置が全然除外されてるる

[籍 35 夋 第 178 號 